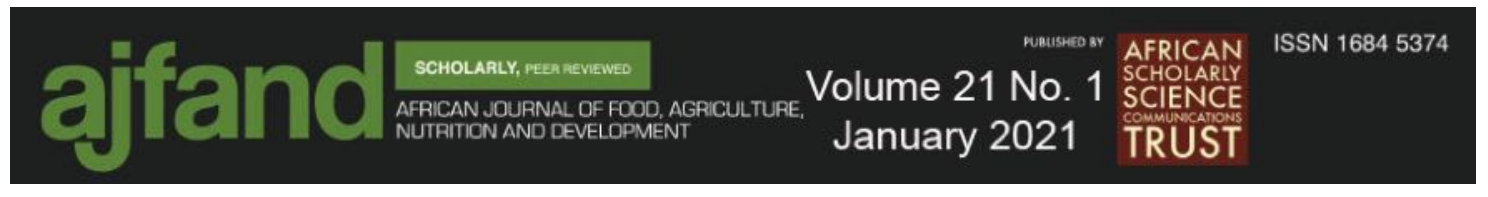

Afr. J. Food Agric. Nutr. Dev. 2021; 21(1): 17343-17364

https://doi.org/10.18697/ajfand.96.19585

\title{
CHARACTERIZATION OF SMALLHOLDER FARMERS AND AGRICULTURAL CREDIT INSTITUTIONS IN RWANDA
}

$$
\text { Taremwa } \mathrm{NK}^{1 *} \text {, Macharia } \mathrm{I}^{2} \text { and } \mathrm{E} \text { Bett }^{2}
$$

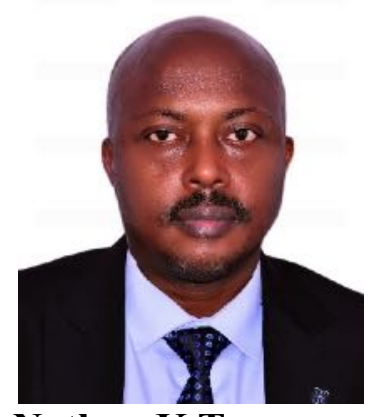

Nathan K Taremwa

*Corresponding author email: nk.taremwa@gmail.com ; nathantaremwa@students.ac.ku.ke

${ }^{1}$ Department of Rural Development \& Agricultural Economics, University of Rwanda, P.O. Box 4285, Kigali, Rwanda

${ }^{2}$ Department of Agricultural Economics, Kenyatta University, P.O. Box 43844-00100, Nairobi, Kenya

${ }^{2}$ Department of Agricultural Economics, Kenyatta University, P.O. Box 43844-00100, Nairobi, Kenya 


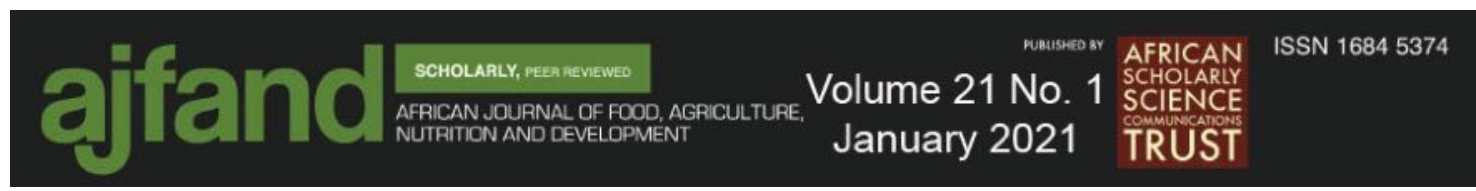

\section{ABSTRACT}

The significance of access to agricultural credit in perpetuating agricultural productivity is unquestionable, because it is a means to achieving optimal productivity. The minimization of any barriers to agricultural credit access should, thus, be a global priority. One of the most significant and current barriers to agricultural credit access is information asymmetry which results into mutual distrust between lending institutions and borrowers in this case the smallholder farmers. To address information asymmetry, both the lending institutions and borrowers need to have definitive descriptive information about either party. Without the profiling of institutions and potential borrowers, an information gap persists, thereby increasing mutual distrust. This study addresses that gap, in the context of Rwanda by characterizing smallholder farmers and agricultural credit institutions. A cross-sectional survey design was used in this study with smallholder farmers and staff in agricultural credit institutions in the Eastern, Western, and Central provinces of Rwanda as the units of analysis. A multistage sampling procedure was used, with stratified sampling of administrative levels spanning from province (stage 1) to districts (stage 2) and sectors (stage 3), followed by a simple random sampling of cells per sector, and the convenience sample of households. Staff in the financial institutions were purposively sampled. The data collected was analyzed using principal component analysis and cluster analysis with the K-means statistic (SPSS version 25). The largest cluster of smallholder farmers has the following characteristics: household size of 1 to 5 people, farmers with education, owning arable land not exceeding a hectare, with more than five years of farming experience, earning from other off-farm activities, with no dependents under five years of age, and renting less than an acre of land. As for agricultural credit institutions, the largest cluster has following compositions: have mechanisms or measures established for managing loan defaults with the majority using refinancing, rescheduling, and collateral release, with variable loan payback options, and provide targeted agricultural credit to farmers such as agricultural input premium. The research findings are particularly pertinent for maize- and ricegrowing farmers, and how to reduce the information gap and the implications of broadening access to credit to smallholder farmers were discussed. This study emphasizes the need for characterization for both parties to be better informed about the characteristics and dynamics of each other, all in a bid to lessen asymmetric information and thus improve access to credit.

Key words: Smallholder farmers, Characterization, Agricultural credit institutions, Information asymmetry 


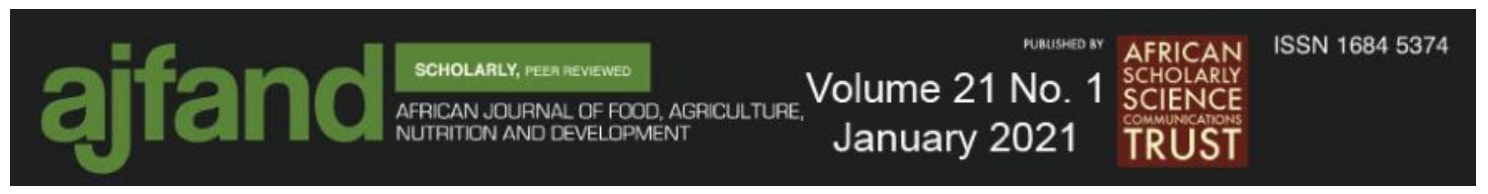

\section{INTRODUCTION}

Information asymmetry, a situation in which there is mutual distrust between a lending institution and borrowers [1] due to a mutual lack of information on the part of either party has been singled out as being critical in determining access to agricultural credit [2 -6]. In an agribusiness context, information asymmetry is typified by a situation in a smallholder farmer is not aware of loan services and options available, credit acquisition procedures and operational dynamics of lending and institutions [7]. Such a situation becomes apparent with concurrent lack of information about the demography and characteristics of smallholder farmers on the part of lending institutions. It is such a gap in information that creates mutual distrust, hence making access to credit, particularly on the part of smallholder farmers challenging [1]. This underscores the need for characterization, so that both parties will be better informed about the characteristics and dynamics of each other, all in a bid to lessen asymmetric information, and thus improve access to credit.

With respect to smallholder farmers, characterization includes a description of the various categories of farmers, their demographics, attributes, production trends, and existing conditions of production systems $[7,8]$. The goal is to portray production categories that are situated in a particular environment of smallholder farmers to determine possible and appropriate financial interventions and policy support suitable for them [7 - 10]. Such information can help agricultural credit institutions plan their financing strategies and policies appropriately, which would also improve the financial options available for smallholder farmers to choose from. To do so, an empirically grounded typology of both smallholder farmers and financial institutions is necessary particularly among rice and maize smallholder farmers. That follows evidence that rice and maize smallholder farmers are cornerstones of food security, especially in the current times when there is an anticipated rise in global population from 7.3 billion today to close to 9.8 billion by 2050 [11].

Maize is the world's most important grain, based on production volume [12, 13], and rice is one of the most widely consumed grains $[14,15]$, which makes them arguably the cornerstones of food security globally $[16,17]$. Global consumption of rice has increased rapidly over the last several years; about 490 million metric tons of rice are currently consumed worldwide [13]. The United Nations Food and Agriculture Organization's (FAO) forecasted rice consumption to reach 509 million tons [18], and that of maize to rise by $16 \%$ by the year 2027 [14,18]. There has thus been a corresponding call for increment in financial investments into smallholder farming globally, which the World Bank estimates at $\$ 80$ billion annually [19]. That in part, follows evidence that agricultural credit is a significant precursor to agricultural productivity as it governs the efficiency of land preparation for cultivation, procurement of farm inputs notably mineral fertilizer, irrigation equipment, and various other agriculture technologies [20, 21]. Despite its crucial role, however, according to the World Bank [19], financial sector in developing countries currently lend a disproportionately lower share of their loan portfolios to agriculture compared to agriculture sector's share of GDP. Information asymmetry is one of the leading factors behind the current agribusiness predicament of 


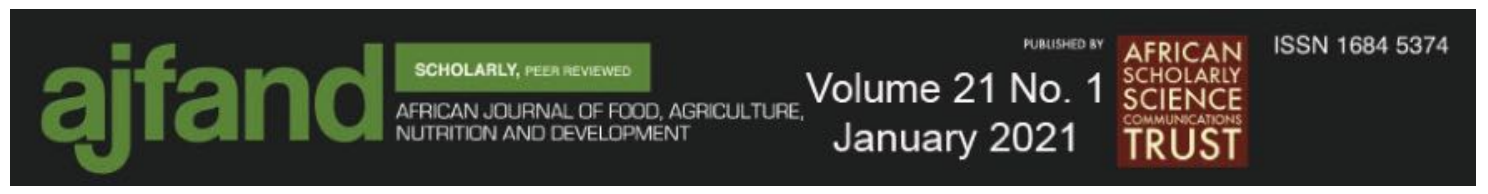

having less than $50 \%$ of the smallholder farmers who need agricultural credit with access to it [19].

In Rwanda, there have been reports of suboptimal access to agricultural credit especially in the Eastern and Western Provinces, which are home to more than 4 million smallholder farmers [22]. Of the proportion of smallholder farmers who applied for an agricultural loan, less than $40 \%$ were smallholder farmers from the two provinces [23]. Despite the strong case for further investigation, only few attempts have been made to characterize smallholder farmers in these regions [for instance 24], and none as far as I know have been made to characterize agricultural credit institutions, let alone cross-matching smallholder farmers' and financial institutions characteristics. Therefore, this study was set out to characterize and analyze smallholder farmers and agricultural credit institutions that provide agricultural credit to smallholder farmers in Rwanda.

\section{MATERIALS AND METHODS}

\section{Study area}

This study had two distinct study populations, one being smallholder farmers and the second being staff in agricultural credit institutions in Rwanda. The eastern and western provinces of Rwanda were the study areas for smallholder farmers, while Kigali city was the study area for staff in agricultural credit institutions. The two provinces (Eastern and Western) were purposively sampled because they are home to the largest population of rice and maize farmers in Rwanda [25], yet those farmers are reported to be among those that have the least access to agricultural credit [23]. Kigali was the study area for staff because every finance institution that provides agricultural credit to smallholders in Rwanda has headquarters in Kigali.

\section{Study design}

Given the interest of the study in the characterization of farmer households, and agricultural credit institutions, all data that were required by the study had to be quantifiable. Hence, the study adopted a cross-sectional survey design.

\section{Sample size and sampling procedure}

The formula by Krejcie and Morgan [26] was adopted to estimate the sample sizes of both the smallholder farmers and finance institution staff. A sample of 422 smallholder farmers (239 of which were from the Eastern province and 183 from the Western province) were studied. The sample size for staff in the agricultural credit institutions was 17 , since one was sampled per institution (17 institutions in total).

\section{Study population}

The first target population was smallholder farmers in the two study areas, Eastern and Western Provinces of Rwanda. The study population was particularly 422 smallholder farmers who were cultivating either rice or maize as a principal crop. They were studied because some of them have been reported to have intermittent access to agricultural credit, despite being among the category of smallholder farmers that has been targeted for financial inclusion [23]. The second study population was staffs working in agricultural credit institutions in Rwanda, particularly those who were working in 


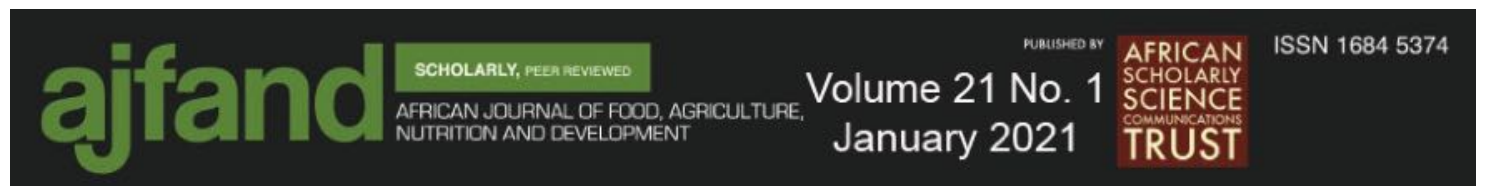

administrative positions at the headquarters of each respective finance institution. The study particularly targeted managerial staff (17), and those who were working in the respective loan departments.

The two regions were stratified into two strata: Eastern (Strata 1) and Western (Strata 2) at provincial level, after which simple random sampling was used to sample the districts (4) in each stratum. Each of the four sampled districts per provincial stratum was stratified so that a representative sample of sectors therein could be sampled. Simple random sampling technique was used to sample the sectors so that sampling bias could still be eliminated. The sectors were stratified and cells therein sampled randomly (simple random sampling). Since there was no systematic arrangement of farm households in each of the cells; it was not feasible to use probabilistic methods to sample them. Hence, convenience sampling was used to sample the households. Once a particular household was reached at, the researcher established rapport with the residents and endeavored to establish whether a given household had an eligible member (farmer growing either rice or maize or both as principal crops) for the study before selection and interviewed.

Given that the members of staff who were targeted in the agricultural credit institutions were about 24, of which 17 of them were required, the principal investigator could not use random sampling to sample both the institutions and staff. Therefore, purposive sampling was used to sample the 17 bank staff. To minimise sampling frame error (few potential respondents), each of the staff that were sampled was engaged in a consenting process, and they were assured of ethical upholding and a short participation duration so as to increase the chances of each of them participating.

\section{Types of data and methods of collection}

Being quantitative, structured interviews were used to obtain primary data from both the smallholder farmers and finance institution staff. Structured questionnaires were used to capture data from the respondents (smallholder farmers and agricultural credit institutions' staff). The questionnaire for smallholder farmers was designed with two sections (demographic and individual characteristics), and the institutional questionnaire too was designed with two sections (demographic and finance institution characteristics).

\section{Analytical techniques}

The data entry process was started with the entry of all variable labels and according each of them with appropriate values in SPSS version 25. It is within that software that principal component and cluster analysis were conducted. Smallholder farmer characterization was done by using two consecutive multivariate statistical techniques: one being principal component analysis (PCA) and the second being cluster analysis (CA). As per Kaiser's criterion, all factors (demographic, household and institutional characteristics) that had an Eigen value of 1 or greater were retained and considered for cluster analysis. When it came to cluster analysis, one step was used to determine the number of clusters that is the K-means clustering method. Using the K-means method, the principal components determined using the PCA method were fitted and clustering started, following which cluster membership in each cluster was established and reported 


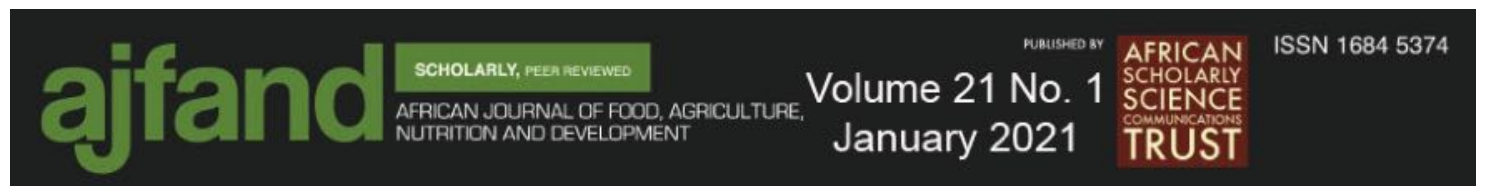

accordingly. However, in order to determine the distribution of each of the principal components in the largest clusters, cross tabulation analysis was also conducted.

\section{RESULTS AND DISCUSSION}

\section{Farmer and agricultural credit institution staff characteristics}

More than half of the farmers sampled were male (58.8\%), and close to a third of them were youths in the age range of $29-39$ years $(31.0 \%)$. More than two thirds of the respondents reported that they were the heads of the households (69.9\%). For those who were not household heads, more than three quarters of them reported that they were wives $(84.0 \%)$. More than three quarters of the respondents reported that they had received some form of formal education $(84.1 \%)$, with more than half of them had attained Primary (Upper) education (56.6\%).

More than two thirds of the staff were male (70.5\%), married (70.5\%) and all were occupying managerial positions $(100 \%)$ in the institutions that they were sampled at.

\section{Characterization of farms of smallholder farmers in the Eastern and Western Provinces of Rwanda}

Table 1 shows the variables that were considered for principal component analysis. Of the 25 variables, 10 components emerged as principal components with Eigen values greater than 1, as confirmed by the scree plot in Figure 1. The first component [C1], which explains $8.6 \%$ of variance, is referred to as off farm activities engaged in by the smallholder farmer. The second component [C2] is the number of children less than five years in the household and the third component [C3] whether farmers had savings in any banking institution.

The fourth component [C4] is the size of land owned. The fifth component [C5] is about the number of plots of own land. Component 6 [C6] refers to the size of the household. The seventh component [C7] concerns receiving formal education. The eighth component [C8] indicates farmer's gender, the ninth component [C9] is whether farmers rent land and the tenth component [C10] shows farmers' experience in agriculture (in years). 

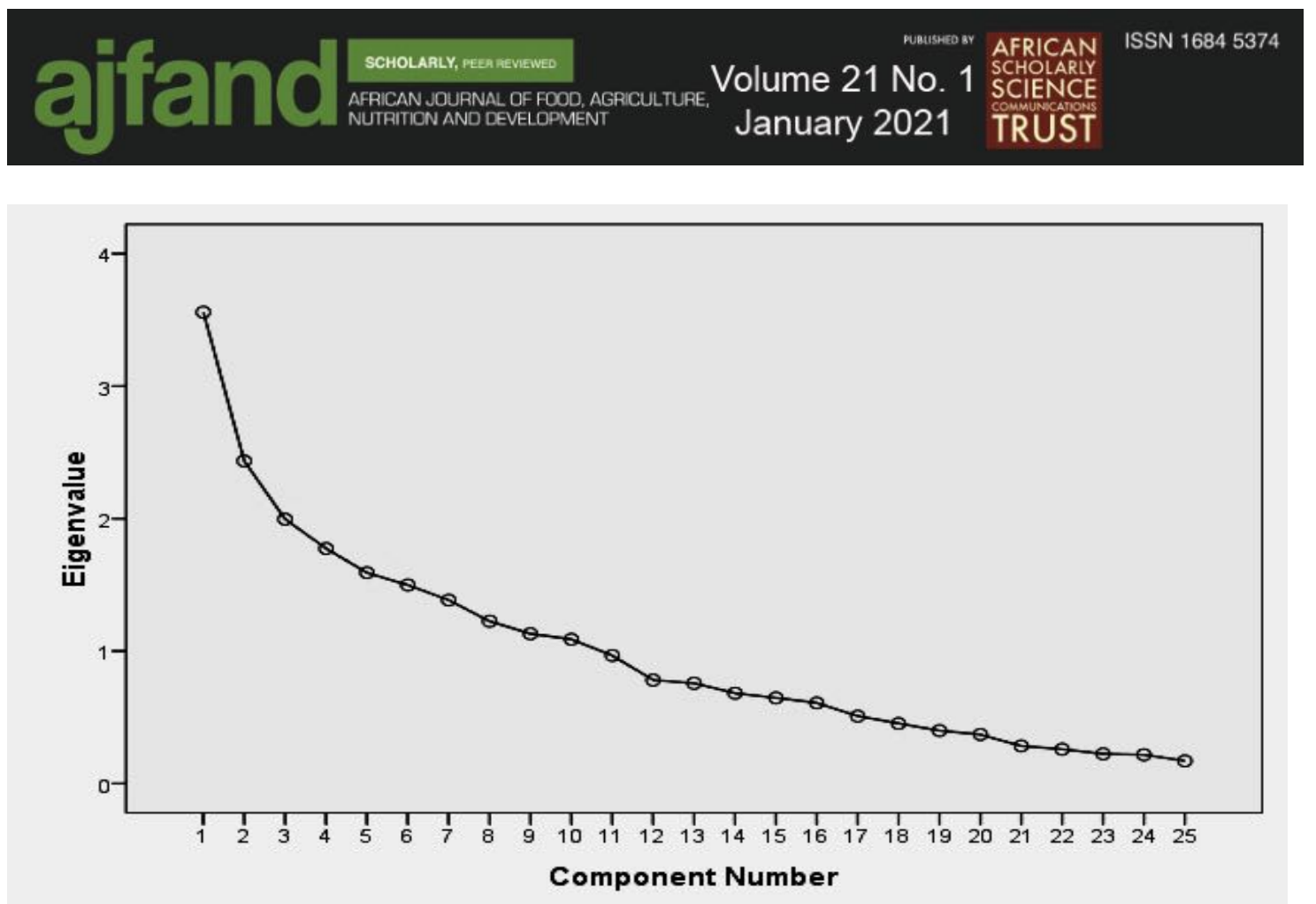

\section{Figure 1: Scree plot indicating the number of smallholder farmer characteristic variables with Eigen values greater than 1}

Cluster analysis revealed that smallholder farmer households in the two provinces belong to 4 clusters, of which the largest cluster was cluster 1 . Using the K-means statistic, cluster membership was analyzed, and the findings showed that cluster one which comprised of $67 \%$ of the households sampled is the largest cluster. In order to ascertain the precise descriptions of the smallholder farmers in this cluster, a cross tabulation was run between each of the definitive variables $(>1)$ in Table 2 and the resultant cluster number of cases from the $\mathrm{K}-$ means cluster analysis. The cross-tabulation findings are shown in Table 3. The findings indicate that cluster 1, is made up of mainly households of between 1-5 people, farmers with formal education, cultivatable land not exceeding a hectare, farmers with more than five years of agricultural experience, farmers earning from off-farming activities, with no child under five years of age, and households which rented less than an acre of land.

The first defining characteristic of smallholder households in Rwanda is their household size, similar to findings by in Ghana $[27,28]$. The majority of the smallholder farmer households (56.9\%) in the Eastern and Western provinces of Rwanda are made up of 1 - 5 people, similar to findings from a Ugandan smallholder farmer's survey [29]. The implication of this finding is that rice and maize smallholder farmers in the Eastern and Western provinces of Rwanda could be having challenges meeting farm labor demands from its household members, which are essential source of labor for smallholder farms that are less than 2 acres. A household with 1 to 5 members typically relates to having two adults (parents), and school-aged children, who cannot contribute to farm labor. Coupled with the fact that access to credit among the farmers is low, and the lack of mechanization, a shortage of cheap household labor could be a factor in explaining the low productivity in rice and maize productions in Rwanda [30, 31]. 


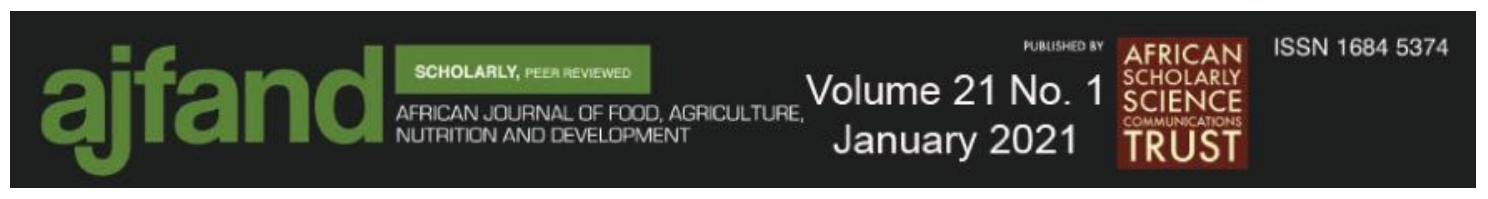

Contrary to the findings in Madagascar [32] and Ferreira in Malawi [33], rice and maize farmers in the Rwanda had all received formal education. Having the majority of the smallholder farmers with formal education could positively influence accessing agricultural credit, all other factors being constant.

Most of the smallholder farmers cultivated less than a hectare of land, similar to findings by Sitko [34] and Larson [35]. This could be one of the factors behind the low access to agricultural credit among smallholder farmers in Rwanda, given that land is used as collateral in credit disbursement. Besides being taken as collateral, a small land size has further negative implications on agricultural productivity. The advantages of agricultural mechanization at a higher scale of production are known to have greater productivity, but such benefits are not feasible on small, scattered plots of land. That can, therefore, make financial institutions whose credit ceilings are based on productivity become hesitant to disburse credit to farmers with small parcels of land. Worse still, the findings showed that even those who rented additional land to supplement their cultivation were renting less than an acre of land. While renting extra land for agribusiness has been acknowledged to be a predictor of higher agricultural productivity, this may not be the case for most of the rice and maize smallholder farmers in Rwanda. That is because even after combining their own and rented land, the size of land would not make a significant difference in productivity given that most of the farmers were not using modern inputs. Similarly, chances of accessing agricultural credit do not increase either, given that land is taken as collateral for agricultural credit only if it is owned [36, 37], and given the marginal increments in productivity, the condition of loan ceiling based on $70 \%$ productivity also hampers access.

The other defining characteristic of smallholder farmers in the Eastern and Western provinces was that most of them had smallholder farmer experience of more than five years, which in some studies [38], has been found to be protective of access to credit. Experienced farmers are more likely to have access to more arable land, have adopted (or inclined to) mechanization, and modern farming techniques, and be more aware of the procedural dynamics of obtaining agricultural credit. Therefore, we argue that rice and maize smallholder farmers in Rwanda seem to meet the requisite personal characteristics necessary to access credit.

The findings of this study showed that about a third of the smallholder farmers were engaged in off-farm activities. That is, had other business enterprises besides agriculture from which they obtained income. This characteristic is generally seen as favorable to access to agricultural credit, given that having extra income earnings could serve as a reassurance for credit repayment ability. Off-farm activities have been known to reduce income uncertainty as income from off-farm can be used to reimburse any shortfalls in farm incomes, hence making it less likely for a smallholder farmer to default on agricultural credit payment. Secondly, with off-farm incomes, comes income diversification and smoothing of risks across different activities, which could potentially further reduce income uncertainty and open up opportunities to invest in improved production technologies to enhance agricultural production. Continuing with this logic, it is possible to imagine the increase in agricultural productivity leading into greater 


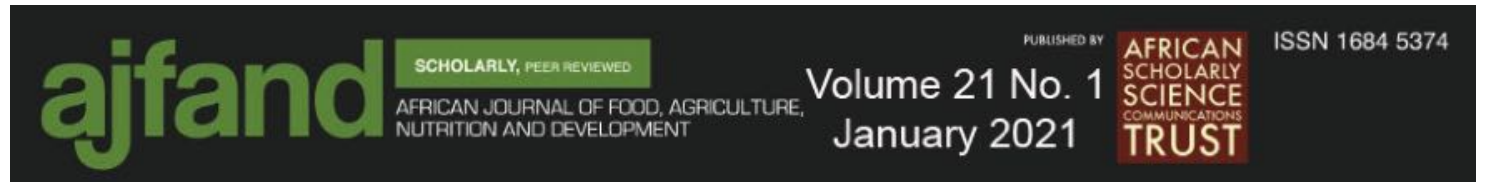

ability to access larger amounts of agricultural credit from institutions that match loan ceilings with the level of agricultural productivity.

The final characteristic that defined the largest cluster of farming households in the study was the absence of children under five years of age. This finding does not necessarily mean that all farm households do not have children, but rather that about 7 in every 10 of those households do not have children in the age of 5 years and below. The other implication of the finding is that about 7 in 10 of the households may be having children between the ages of 6 and 12 years. Such a finding, in the context of agribusiness implies that smallholder farmers potentially had sufficient family farm labor at their disposal. The absence of children in the households means that family members can be considered to be able to provide for farm labor. The findings imply that a considerable proportion of rice and maize smallholder farmers in the eastern and western provinces of Rwanda are less challenged by labor shortages, as has been reported to be the case in some countries. Therefore, even with small plots of land, agricultural productivity can to a large extent be guaranteed as well as income uncertainty, most especially if all the adults in the farm household have an off-farm business. This in turn increases the propensity of such households to access agricultural credit.

\section{Characterization of agricultural credit institutions}

Although there would have been 20 variables in the factor loading of financial institutions' characteristics, it was discovered that 6 of them had zero standard deviation and so could not be included in the factor analysis. Therefore, only 14 were included as shown in Table 4. Three principal components defined the basis of financial institution characterization with Eigen values above 1. Three principal components in the factors were loaded, as illustrated by the scree plot in Figure 2

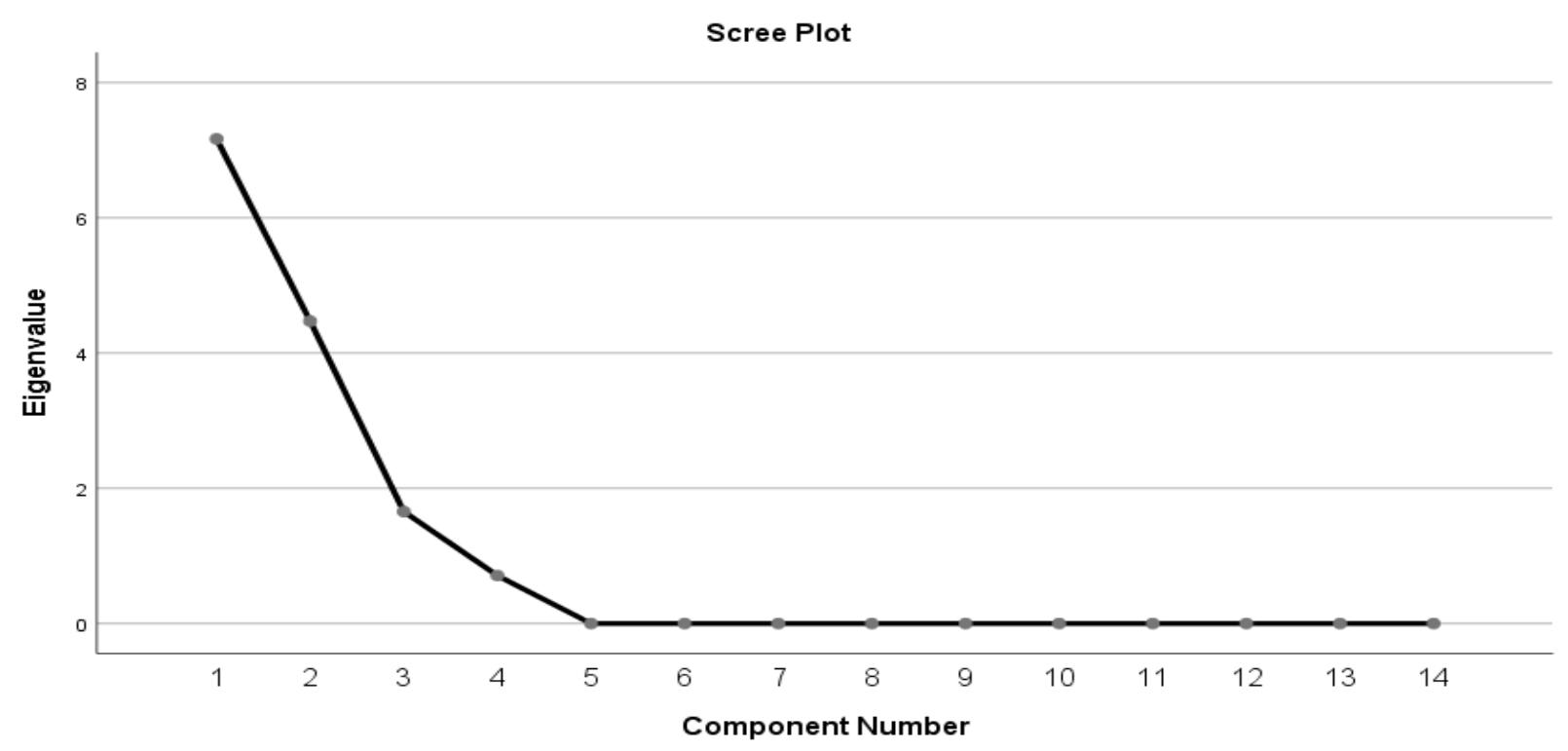

Figure 2: Scree plot indicating the number of finance institution characteristic variables with Eigen values greater than 1 


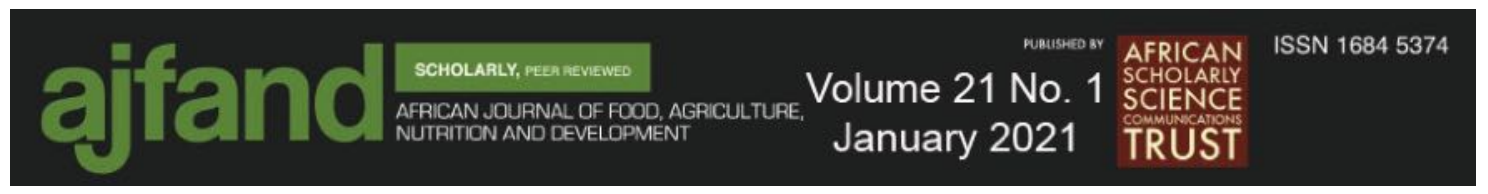

Component 1 (C1) of the three principal components (Table 4) is correlated with characteristics including; 1) the duration of financial service provision, 2) requirements for accessing credit, 3) type of targeted agricultural credit, 4) the number of smallholder farmers who apply for agricultural credit annually, 5) whether the institutions have any established ceiling rates for lending to farmers, 6) whether the institutions require any collateral from borrowers, 7) the form of collateral usually required before loan disbursement, and lastly 8) the mechanisms or measures established for loan defaulters. This component is defined as the mechanisms or measures established for loan defaulters $(\mathrm{r}=0.945)$.

Component 2 (C2) is correlated with 1) type of agricultural credit institution, 2) the number of farmers who applied for agricultural credit annually, 3) the form of collateral usually required, 4) the length of payback period for agricultural credit, and 5) the perception of agricultural risk. The component is more correlated with the length of payback period for agricultural credit, which is its defining variable $(\mathrm{r}=0.988)$.

Component 3 (C3) is defined by variables including, 1) the provision of any targeted agricultural credit to farmers producing maize and rice, and 2) the interest rate to borrowers. The component is strongly correlated with the provision of targeted agricultural credit to the maize and rice farmers $(r=0.916)$.

Going by the K-means clustering and the cluster membership provided in Table 4, cluster 2 comprised the biggest cluster, with all the three earlier identified principal components remaining important in the cluster (Table 5). To determine the distribution of the principal components identified earlier, in cluster 2, a cross-tabulation was also run between the components and the cluster number of cases (Table 6). Cluster 2 is made up of financial institutions that have refinancing, rescheduling, and foreclosure, as the mechanisms or measures established for managing loan defaults $(78.6 \%)$, whose loan payback period is variable (not fixed) $(57.1 \%)$, and those that provide targeted agricultural credit to farmers (64.3\%) (Table 6).

In Rwanda, the agricultural credit institutions employ both on-balance sheet (internal) and off-balance sheet (external) mechanisms to reduce stock of non-performing loans [39]. However, based on the three prominent mechanisms that were observed in this study, two are internal recovery mechanisms and one is an external write-off mechanism. Therefore, agricultural credit institutions in Rwanda employ a mix of strategies to manage high risk loans, from which they can flexibly select depending on the conditions, hence making the institutions more adaptive in managing potentially high-risk loans, even in the context of smallholder farmers. For instance, the on-balance sheet mechanism of refinancing allowed farmers to get an additional loan to service the old one, which could in certain condition even reduce interest rate. This mechanism could not only enhance loans management, but could also send a positive message (and reassure) to farmers that on-balance sheet approaches could help farmers' gradual pay off loans over the medium- to long-term.

However, the findings further indicate that the agricultural credit institutions considering using only on-balance sheet mechanisms could be seen negatively by smallholder 


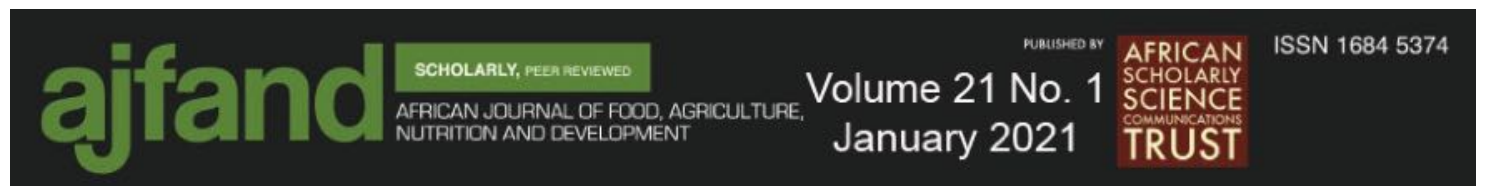

farmers. This is because when farmers have to put some of their land as collateral, they are hesitant to access credit from an institution that emphasizes using of restructuring, liquidation, or foreclosure activities in case of default. With such sanctioning mechanisms, the risk of losing one's collateral, in this case land can be heightened, which for a smallholder farmer would be a significant dissuader. This could be one of the reasons why access to credit among smallholder farmers in Rwanda could still be low.

Another key feature that defined the institutions was the targeted agricultural credit for farmers, which means that most agricultural credit institutions in the country provided direct or indirect financing. This is an indication that agricultural credit institutions are by and large aware of their role in promoting the investment and development of the agricultural sector. However, the finding indicated that between direct financing and agricultural input premiums, most of the institutions had the latter on offer. The implication of this is that most agricultural credit institutions require a smallholder farmer to have a certain amount of money for purchase of inputs, upon which premiums can be provided to enable the smallholder farmer's purchase whatever they want to. Thus, agricultural input premiums, although quite enabling, are evidently limited to smallholder farmers who already have cash and savings at bank, which is not always the case for most of the smallholder farmers who have no off-farm activities, and own small pieces of land.

With the presence of only such a kind of financing strategy in most available institutions and not a variety of smallholder tailored strategies, interest in accessing credit from thereat can be reduced. This could also in part be behind the findings that most of the institutions receive smallholder loan applications that constitute less than $1 \%$ of the country's smallholder farmer population. Therefore, the majority of the smallholder farmers are missing out on the numerous advantages of direct financing including loans for land purchases, loans for pre-harvest and post-harvest activities, loans for agriculture and allied activities, loans for purchase and distribution of fertilizers, pesticides, seeds, loans, loans to farmers through Primary Agricultural Credit Societies (PACS), loans to cooperative societies, loans for construction and running of storage facilities (warehouses, market yards, and silos). There could be a number of reasons behind the non-availability of both direct financing strategies for smallholder farmers, chief among which could be asymmetry of information on the part of the institutions, as a result of high-risk profiling of default amongst the rural population. The lack of direct and indirect financing strategies could also be, in part, responsible for the sub-optimal amounts of rice and maize domestic production. Given that such financing strategies include the provision of farmers with improved/modern inputs, and it also includes preharvest financing, short of which, productivity may be reduced.

The other characteristic that defined agricultural credit institutions in Rwanda was that nearly all of them have variable credit repayment periods. This finding implies that despite the use of mostly on-balance sheet credit default prevention mechanisms, and the relatively lower embracement of direct financing, the institutions in Rwanda provide input premiums and other forms of generic agricultural credit at non-fixed repayment periods. This could be a significant trigger for, and subsequent access to agricultural credit among smallholder farmers, most of whom make sales and profit at harvest. For 


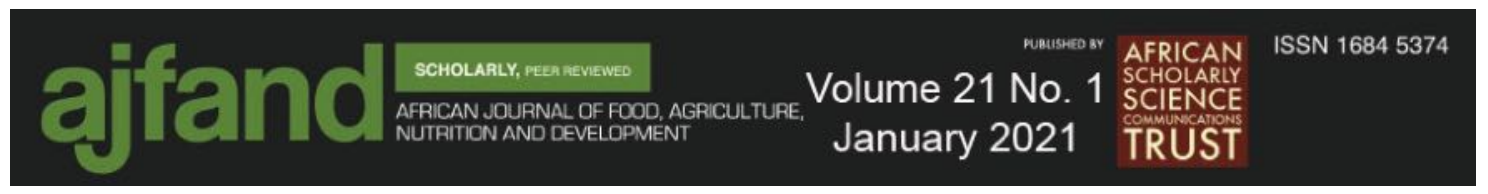

rice and maize farmers, the delay can be up to 5 to 7 months depending on the size of land and volume of harvest. Also, with a non-fixed repayment period, farmers can service their loans within a month of acquiring it, thus lowering costs spent on interest rates, which in its self can also be a significant advantage, if the farmers are made aware of it.

\section{CONCLUSION}

Smallholder farmers in the Eastern and Western provinces of Rwanda are characterized as follows: male-headed households with some ownership of land, educated, cultivating less than a hectare of land, have farming experience of five years and more, engage in other off-farm economic activities, with no dependents under five years of age, and renting less than an acre of land. The financial institutions which provide agricultural credit to these farmers were found to have the following characteristics: have mechanisms or measures established for managing loan defaults (with the majority using refinancing, rescheduling, and collateral release), with variable (and not fixed) loan payback options, and provide targeted agricultural credit such as agricultural input premium.

As the typology of smallholder farmers in Rwanda reveals, it is evident that the education of smallholder farmers and ownership of land with substantial farming experience enables them to access agricultural credit. This should let proprietors of agricultural credit institutions know that the commonly-held view of famers being in the high-risk category needs to be re-evaluated.

From an institutional perspective, it is suggested that the institutions consider adjusting agricultural credit disbursement and management strategies to broaden their portfolios. Some of the examples of adjustments that may be considered include: the adoption of both on-balance sheet and off-balance sheet credit management strategies, use of foreclosure as a last resort and not as the primary recovery strategy, and instead, adopting a refinancing strategy in cases of risk of default. Doing so will help reduce some of the uncertainty that most smallholder farmers have and their reluctance to take on loans for the fear of the likelihood of foreclosure.

It is necessary for agricultural credit institutions that have not yet adopted the targeted agricultural credit to smallholder farmers in the country to do so. Financing options such as matching grants, technical assistance, direct financing, input premiums and inputbased finance improve not only access to the credit market but they also have a positive and significant influence on agricultural productivity. Given the premise that such financing will increase the use of productivity-enhancing inputs, and that the increased productivity and income of the smallholders will help pay back the loan, this could generate a positive amplifying effect by increasing loan applications on the part of the farmers and with more payout from the institutions, which will create more confidence and lower the perception of risk or chance of default. Agricultural credit institutions should also consider carrying out more marketing campaigns and sensitization drives in rural areas to inform farmers about direct and indirect financing options that are already available. Most of the farmers in our study had no idea of such information. 


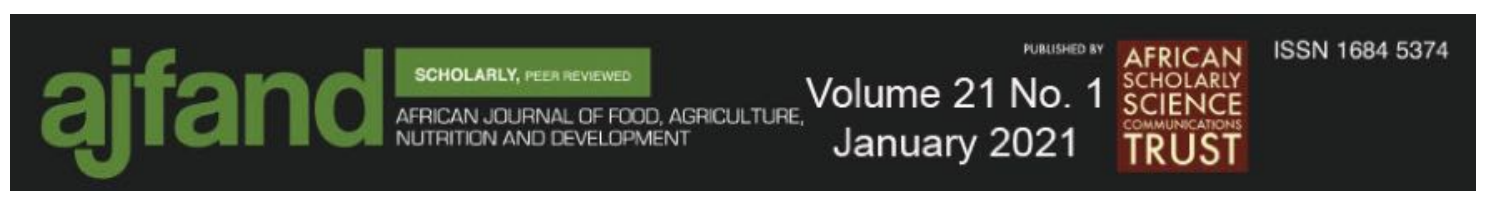

While non-fixed credit repayment periods appeal to many smallholder farmers, it is currently offered by about half of the agricultural credit institutions in Rwanda. Thus, more agricultural credit institutions could consider having not only fixed term credit offers but also variable time loan repayment conditions which could further lower the barrier to access to credit for rice and maize smallholder farmers.

\section{ACKNOWLEDGEMENTS}

The authors are grateful to the Regional Forum for Capacity Building in Agriculture (RUFORUM) for financial support especially during data collection in Rwanda. The smallholder farmers and agricultural credit institutions were collaborative and shared at liberty the necessary information. We truly express our sincere thanks for their valuable time and necessary support that made this research successful. Finally, the authors appreciate Dr. Sung Kyu Kim for reviewing and commenting the earlier draft of this manuscript.

\section{CONFLICT OF INTEREST}

The authors declare that there was no conflict of interest in this study. 


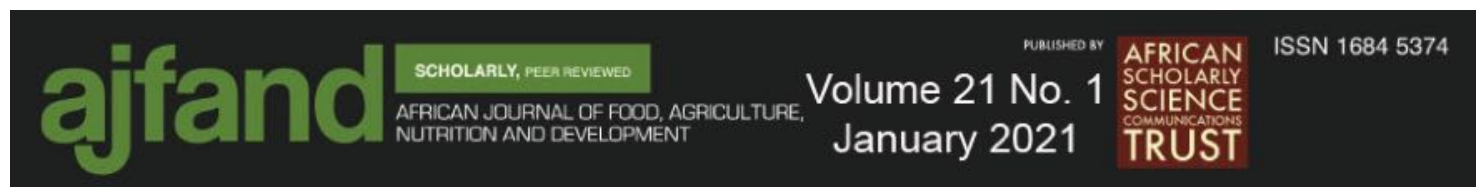

Table 1: Principal component analysis [Farm typologies]

\begin{tabular}{|c|c|c|c|c|c|c|c|c|c|c|}
\hline Factor & $\mathrm{C1}$ & $\overline{\mathrm{C2}}$ & $\overline{C 3}$ & $\overline{C 4}$ & $\overline{C 5}$ & $\overline{\mathrm{C6}}$ & $\overline{C 7}$ & $\mathrm{C8}$ & C9 & $\mathrm{C10}$ \\
\hline Received formal & 8 & 0.144 & -0.023 & 0.020 & 0.033 & -0.155 & 0.821 & -0.089 & 0.072 & -0.055 \\
\hline Size of household & -0.076 & -0.119 & 0.008 & 0.062 & -0.010 & 0.780 & -0.194 & 0.066 & -0.057 & -0.027 \\
\hline $\begin{array}{l}\text { Household members provide labor } \\
\text { for cultivation }\end{array}$ & -0.017 & 0.339 & 0.286 & 0.148 & 0.304 & -0.497 & -0.459 & -0.155 & 0.069 & 0.030 \\
\hline $\begin{array}{l}\text { Number of household member } \\
\text { working on farm }\end{array}$ & -0.044 & 0.439 & 0.069 & -0.293 & 0.113 & 0.582 & 0.073 & -0.135 & 0.122 & 0.030 \\
\hline $\begin{array}{l}\text { Household head participates in off- } \\
\text { farm activities }\end{array}$ & 0.002 & 0.330 & 0.131 & 0.056 & 0.147 & 0.061 & -0.031 & 0.408 & -0.443 & -0.037 \\
\hline Off farm activities & 0.765 & 0.043 & -0.015 & -0.020 & -0.130 & -0.039 & -0.064 & -0.152 & 0.029 & -0.052 \\
\hline $\begin{array}{l}\text { Number of children under five years } \\
\text { in household }\end{array}$ & -0.079 & -0.743 & 0.062 & -0.031 & 0.017 & 0.122 & -0.257 & -0.154 & -0.064 & 0.057 \\
\hline Duration as smallholder farmer & -0.134 & 0.170 & 0.001 & 0.169 & -0.009 & 0.126 & -0.217 & 0.085 & -0.037 & 0.705 \\
\hline Own the piece of land cultivated on & 0.031 & -0.251 & -0.116 & 0.192 & 0.505 & -0.071 & 0.096 & 0.264 & -0.295 & 0.298 \\
\hline Kind of crops periodically cultivated & 0.214 & 0.117 & -0.138 & 0.080 & 0.806 & -0.167 & -0.032 & 0.008 & 0.050 & 0.053 \\
\hline $\begin{array}{l}\text { Have any other source of income, } \\
\text { besides agribusiness }\end{array}$ & 0.082 & -0.076 & 0.556 & 0.051 & -0.017 & 0.244 & 0.393 & 0.354 & -0.227 & -0.124 \\
\hline Where farmer saves money & 0.008 & -0.124 & 0.809 & 0.225 & -0.092 & -0.025 & -0.212 & -0.024 & 0.051 & -0.039 \\
\hline Household own land for farming & -0.118 & -0.137 & 0.141 & 0.083 & 0.809 & 0.177 & -0.011 & -0.163 & -0.037 & -0.109 \\
\hline Size of land owned & 0.133 & 0.107 & -0.082 & 0.827 & 0.186 & -0.007 & 0.171 & 0.043 & -0.049 & 0.101 \\
\hline $\begin{array}{l}\text { Household currently renting any } \\
\text { land for farming }\end{array}$ & 0.000 & 0.072 & 0.020 & 0.118 & 0.006 & -0.014 & 0.022 & 0.106 & 0.856 & -0.031 \\
\hline Size of land rented & -0.382 & -0.283 & 0.292 & 0.054 & -0.083 & 0.016 & 0.312 & -0.101 & 0.409 & 0.362 \\
\hline Number of crop types grown & 0.352 & 0.016 & -0.047 & -0.179 & 0.066 & -0.274 & 0.172 & -0.068 & 0.051 & 0.624 \\
\hline Produce maize or rice or both & 0.292 & 0.364 & -0.382 & 0.032 & 0.101 & -0.387 & -0.317 & 0.238 & 0.039 & -0.006 \\
\hline $\begin{array}{l}\text { Use any chemical inputs during } \\
\text { cultivation }\end{array}$ & 0.347 & 0.435 & -0.313 & -0.429 & 0.153 & -0.254 & -0.087 & 0.026 & 0.176 & 0.072 \\
\hline $\begin{array}{l}\text { Use any biological inputs during } \\
\text { cultivation }\end{array}$ & 0.540 & -0.008 & -0.208 & 0.008 & 0.071 & 0.035 & 0.038 & 0.603 & 0.180 & 0.024 \\
\hline Cropping systems usually practiced & 0.004 & 0.018 & -0.093 & -0.806 & -0.088 & 0.088 & 0.178 & 0.127 & -0.218 & 0.009 \\
\hline Practice terrace farming & 0.718 & -0.056 & -0.082 & 0.145 & 0.223 & -0.085 & -0.037 & 0.001 & -0.117 & 0.079 \\
\hline Farmer gender & 0.264 & -0.021 & -0.072 & 0.104 & 0.146 & 0.015 & 0.088 & -0.710 & -0.017 & -0.037 \\
\hline Current age & -0.126 & 0.730 & -0.046 & 0.079 & -0.196 & 0.040 & -0.130 & -0.110 & -0.133 & 0.298 \\
\hline $\begin{array}{l}\text { Member of any farmers' } \\
\text { organization / cooperative/tontine }\end{array}$ & 0.301 & -0.097 & -0.727 & 0.319 & -0.105 & 0.054 & -0.070 & 0.006 & -0.054 & -0.070 \\
\hline Cumulative percentage & $\overline{8.689}$ & 17.158 & 26.839 & 33.219 & 40.924 & 47.679 & 54.011 & 59.927 & 65.641 & 70.720 \\
\hline
\end{tabular}




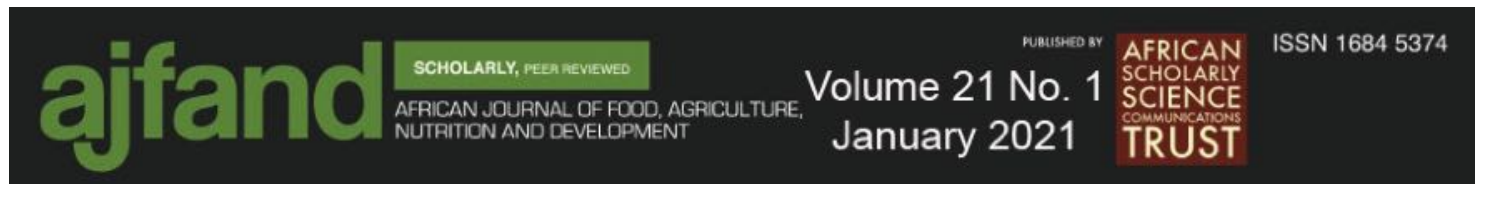

Table 2: Final cluster centers

\begin{tabular}{|c|c|c|c|c|}
\hline \multirow[b]{2}{*}{ Variables } & \multicolumn{4}{|c|}{ Cluster } \\
\hline & 1 & 2 & 3 & 4 \\
\hline Size of household & 1.50 & 1.40 & 2.00 & 1.64 \\
\hline Received any formal education & 1.43 & 1.00 & 0.67 & 0.82 \\
\hline $\begin{array}{l}\text { Size of land owned during the past } 12 \\
\text { months }\end{array}$ & 3.14 & 2.40 & 3.33 & 2.91 \\
\hline Respondent's gender & 0.59 & 0.80 & 1.00 & 0.55 \\
\hline Duration as smallholder farmer & 6.93 & 3.60 & 7.00 & 7.00 \\
\hline Where farmer usually saves money & 1.09 & 1.80 & 1.67 & 4.14 \\
\hline Off farm activities engaged in & 2.64 & 2.80 & 4.33 & 2.18 \\
\hline Household owns land for farming & 0.97 & 1.00 & 1.00 & 1.00 \\
\hline $\begin{array}{l}\text { Number of children under five years in } \\
\text { household }\end{array}$ & 1.71 & 2.00 & 4.67 & 2.00 \\
\hline Size of land household is renting & 2.33 & 1.40 & 3.33 & 2.82 \\
\hline
\end{tabular}




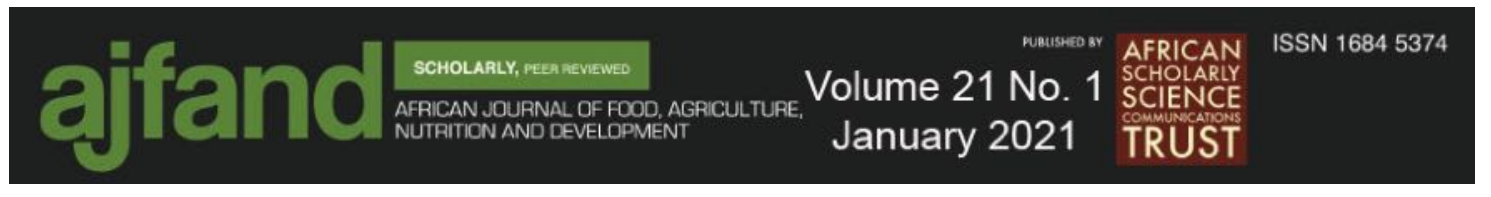

Table 3: Cross tabulation for the description of cluster members in the largest cluster (Cluster 1)

\begin{tabular}{|c|c|c|c|c|}
\hline \multirow[b]{2}{*}{ Variable } & \multicolumn{4}{|c|}{ Cluster number of cases } \\
\hline & Cluster 1 & Cluster 2 & Cluster 3 & Cluster 4 \\
\hline \multicolumn{5}{|l|}{ Size of household } \\
\hline $1-5$ & $33(56.9 \%)$ & $3(60.0 \%)$ & $1(33.3 \%)$ & $9(40.9 \%)$ \\
\hline $6-10$ & $21(36.2 \%)$ & $2(40.0 \%)$ & $1(33.3 \%)$ & $12(54.5 \%)$ \\
\hline More than 10 & $4(6.9 \%)$ & $0(0.0 \%)$ & $1(33.3 \%)$ & $1(4.5 \%)$ \\
\hline \multicolumn{5}{|c|}{ Receive any form of formal education } \\
\hline No & $4(6.9 \%)$ & $0(0.0 \%)$ & $1(33.3 \%)$ & $4(18.2 \%)$ \\
\hline Yes & $54(93.1 \%)$ & $5(100.0 \%)$ & $2(66.7 \%)$ & $18(81.8 \%)$ \\
\hline \multicolumn{5}{|l|}{ Land size owned } \\
\hline $0-0.1$ ha & $5(8.6 \%)$ & $2(40.0 \%)$ & $0(0.0 \%)$ & $6(27.3 \%)$ \\
\hline $0.1-0.19$ ha & $15(25.9 \%)$ & $0(0.0 \%)$ & $1(33.3 \%)$ & $1(4.5 \%)$ \\
\hline $0.2-0.49$ ha & $14(24.1 \%)$ & $2(40.0 \%)$ & $1(33.3 \%)$ & $5(22.7 \%)$ \\
\hline $0.5-0.99$ ha & $15(25.9 \%)$ & $1(20.0 \%)$ & $0(0.0 \%)$ & $9(40.9 \%)$ \\
\hline $1-1.99$ ha & $9(15.5 \%)$ & $0(0.0 \%)$ & $1(33.3 \%$ & $1(4.5 \%)$ \\
\hline \multicolumn{5}{|c|}{ Work experience in smallholder farming } \\
\hline One year & $0(0.0 \%)$ & $1(20.0 \%)$ & $0(0.0 \%)$ & $0(0.0 \%)$ \\
\hline Two years & $0(0.0 \%)$ & $1(20.0 \%)$ & $0(0.0 \%)$ & $0(0.0 \%)$ \\
\hline Three years & $0(0.0 \%)$ & $2(40.0 \%)$ & $0(0.0 \%)$ & $0(0.0 \%)$ \\
\hline Four years & $0(0.0 \%)$ & $(1(20.0 \%)$ & $0(0.0 \%)$ & $0(0.0 \%)$ \\
\hline Five years & $4(6.9 \%)$ & $0(0.0 \%)$ & $0(0.0 \%)$ & $0(0.0 \%)$ \\
\hline Above five years & $54(93.1 \%)$ & $0(0.0 \%)$ & $3(100.0 \%)$ & $22(100.0 \%$ \\
\hline \multicolumn{5}{|l|}{ Off farm activities } \\
\hline Casual labor & $16(27.6 \%)$ & $0(0.0 \%)$ & $0(0.0 \%)$ & $10(45.5 \%)$ \\
\hline Salaried & $9(15.5 \%)$ & $3(60.0 \%)$ & $0(0.0 \%)$ & $4(18.2 \%)$ \\
\hline Business & $14(24.1 \%)$ & $0(0.0 \%)$ & $0(0.0 \%)$ & $3(13.6 \%)$ \\
\hline Livestock & $18(31.0 \%)$ & $2(40.0 \%)$ & $2(66.7 \%)$ & $4(18.2 \%)$ \\
\hline Driver & $1(1.7 \%)$ & $0(0.0 \%)$ & $1(33.3 \%)$ & $1(4.5 \%)$ \\
\hline \multicolumn{5}{|c|}{$\begin{array}{l}\text { Number of children under five years in } \\
\text { household }\end{array}$} \\
\hline None & $27(46.6 \%)$ & $1(20.0 \%)$ & $0(0.0 \%)$ & $8(36.4 \%)$ \\
\hline One & $22(37.9 \%)$ & $3(60.0 \%)$ & $0(0.0 \%)$ & $6(27.3 \%)$ \\
\hline Two & $8(13.8 \%)$ & $1(20.0 \%)$ & $1(33.3 \%)$ & $8(36.4 \%)$ \\
\hline Three & $1(1.7 \%)$ & $0(0.0 \%)$ & $1(33.3 \%)$ & $0(0.0 \%)$ \\
\hline More than five & $0(0.0 \%)$ & $0(0.0 \%)$ & $1(33.3 \%)$ & $0(0.0 \%)$ \\
\hline \multicolumn{5}{|c|}{ Household renting any land for farming } \\
\hline No & $4(6.9 \%)$ & $0(0.0 \%)$ & $0(0.0 \%)$ & $1(4.5 \%)$ \\
\hline Yes & $54(93.1 \%)$ & $5(100.0 \%)$ & $3(100.0 \%)$ & $21(95.5 \%)$ \\
\hline
\end{tabular}




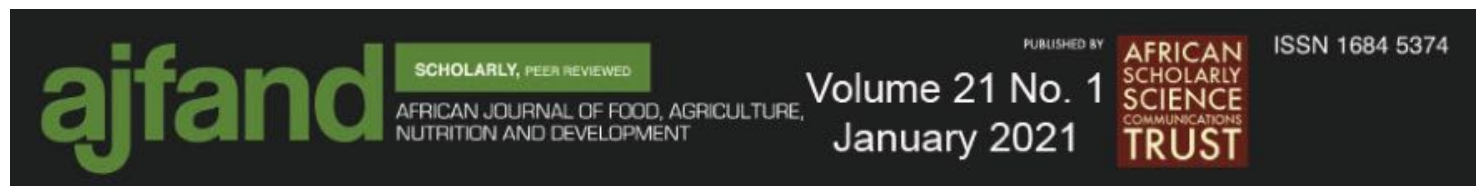

Table 4: Principal component analysis [For agricultural credit institutions]

\begin{tabular}{lccc}
\hline \multicolumn{1}{c}{ Factor } & \multicolumn{2}{c}{ Component } \\
& $\mathbf{C 1}$ & $\mathbf{C 2}$ & $\mathbf{C 3}$ \\
\hline Type of financing institution & -0.049 & $\mathbf{- 0 . 9 9 4}$ & -0.082 \\
Duration of providing financial services to Rwandans & $\mathbf{- 0 . 5 8 3}$ & 0.064 & -0.113 \\
Requirements for accessing credit from institution & $\mathbf{0 . 7 5 8}$ & -0.438 & $\mathbf{0 . 4 6 5}$ \\
Targeted agricultural credit to the smallholder farmers producing Maize & -0.081 & 0.377 & $\mathbf{0 . 9 1 6}$ \\
and Rice & & & \\
Type of targeted agricultural credit & $\mathbf{- 0 . 9 2 5}$ & 0.290 & 0.233 \\
Smallholder farmers who apply for agricultural credit & $\mathbf{0 . 5 8 7}$ & $\mathbf{- 0 . 8 0 7}$ & 0.052 \\
Financing institutions provide agricultural credit to annually & $\mathbf{0 . 8 7 7}$ & -0.447 & -0.165 \\
Have any established ceiling rates for lending to the smallholder farmers & $\mathbf{- 0 . 7 8 7}$ & -0.448 & 0.420 \\
Require any collateral from smallholder farmers & $\mathbf{0 . 7 8 7}$ & 0.448 & -0.420 \\
Form of collateral usually required before loan disbursement & $\mathbf{- 0 . 7 7 1}$ & $\mathbf{0 . 6 3 1}$ & 0.069 \\
Mechanisms or measures established for loan defaulters & $\mathbf{0 . 9 4 5}$ & -0.073 & -0.309 \\
Interest rate for smallholder farmers & 0.317 & 0.474 & $\mathbf{- 0 . 8 2 1}$ \\
Length of payback period for agricultural credit & -0.055 & $\mathbf{0 . 9 9 8}$ & 0.016 \\
Perception of agricultural risk & -0.345 & $\mathbf{0 . 9 2 2}$ & -0.174 \\
\hline$\quad$ Total variance & $\mathbf{4 1 . 7 1 2}$ & $\mathbf{3 6 . 7 1 6}$ & $\mathbf{1 6 . 1 4 9}$ \\
\hline
\end{tabular}

Table 5: Final cluster centers in agricultural credit institutions' typologies

\begin{tabular}{|c|c|c|}
\hline \multirow[b]{2}{*}{ Variable } & \multicolumn{2}{|c|}{ Cluster } \\
\hline & 1 & 2 \\
\hline Mechanisms or measures established & 3.00 & 1.64 \\
\hline Length of payback period & 2.00 & 5.57 \\
\hline $\begin{array}{l}\text { Targeted agricultural credit to smallholder farmers producing maize } \\
\text { and rice }\end{array}$ & 1.00 & 1.36 \\
\hline
\end{tabular}




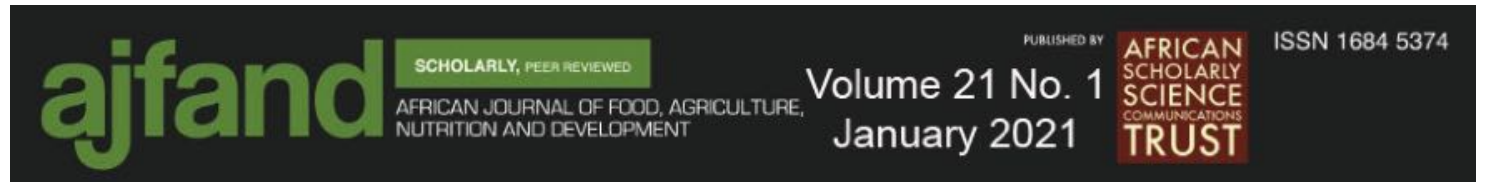

Table 6: Cross tabulation to show descriptions of each variable in the largest cluster (Cluster 2)

\begin{tabular}{lcc}
\hline \multicolumn{1}{c}{ Variable } & \multicolumn{2}{c}{ Cluster number of cases } \\
\hline \multicolumn{1}{c}{ Cluster 1 } & Cluster 2 \\
\hline Rechanisms or measures established & & \\
Sell out collateral & $0(0.0 \%)$ & $11(78.6 \%)$ \\
Refinance and insurance use & $3(100.0 \%)$ & $0(0.0 \%)$ \\
Payback period for agricultural credit from financial & $0(0.0 \%)$ & $3(21.4 \%)$ \\
institution & & \\
One year & & \\
More than three years & $3(100.0 \%)$ & $0(0.0 \%)$ \\
Variable - not fixed & $0(0.0 \%)$ & $6(42.9 \%)$ \\
Provide targeted agricultural credit to the smallholder & & $8(57.1 \%)$ \\
farmers & $0(0.0 \%)$ & \\
Yes & & \\
No & & \\
\hline
\end{tabular}




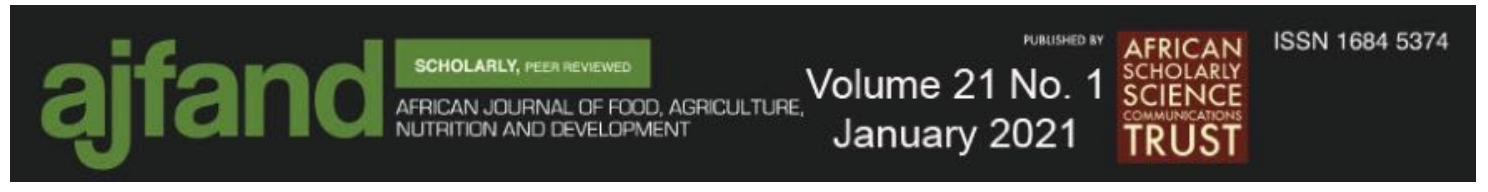

\section{REFERENCES}

1. Rondhi M, Imelda S, Setyawan H, Aji J, Hariyati Y, Raharto S, Fauziah Dand A Kusmiati Asymmetric information and farmer's participation in tobacco contract farming. JEJAK. 2020; 13: 84-102. 10.15294/jejak. v13i1.17413.

2. Niinimäki JP Collateral in credit rationing in markets with asymmetric information. The Quarterly Review of Economics and Finance. Review of Economics and Finance. 2018; 68: 97-102.

3. Hung PD Determinants of new small and medium enterprises (SMEs) access to bank credit: case study in the Phu Tho Province, Vietnam 2017. International Journal of Business and Management 2017; 12 (7): 83.

4. Zegarra L Information asymmetries and agricultural credit. Agricultural Finance Review 2019; 79 (2): 217-233. https://doi.org/10.1108/AFR-08-2018-0062

5. Wang $\mathbf{X}$ and $\mathbf{H}$ Guangwen Digital Financial Inclusion and Farmers' Vulnerability to Poverty: Evidence from Rural China. Sustainability 2020;12: 1668. https://doi.org/10.3390/su12041668

6. Ullah A, Arshad M, Kächele H, Zeb A, Mahmood N and K Müllera Socioeconomic analysis of farmers facing asymmetric information in inputs markets: evidence from the rainfed zone of Pakistan. Technology in Society 2020; 63:101405.

7. Mitra S, Dilip M, Maximo $\mathbf{T}$ and $\mathbf{V}$ Sujata Asymmetric Information and Middleman Margins: An Experiment with Indian Potato Farmers. The Review of Economics and Statistics, MIT Press 2018; 100(1): 1-13.

8. Devotha G, Nyambo ET, Luhanga and $Q$ Zaipuna A Review of characterization approaches for smallholder farmers: Towards predictive farm typologies. The Scientific World Journal 2019; Article ID 6121467: 9. https://doi.org/10.1155/2019/6121467

9. Lopez-Ridaura SR, Frelat MT, van Wijk D, Valbuena T, Krupnik J and ML Jat Climate smart agriculture, farm household typologies and food security: An ex-ante assessment from Eastern India Agricultural Systems 2018; 159: 57-68.

10. Goswami R, Chatterjee $\mathbf{S}$ and B Prasad Farm types and their economic characterization in complex agro-ecosystems for informed extension intervention: study from coastal West Bengal, India. Agricultural and Food Economics 2014; 2(5): 1-24.

11. World Bank. Agriculture Finance \& Agriculture Insurance 2019. Retrieved 23 October 2019 from

https://www.worldbank.org/en/topic/financialsector/brief/agriculture-finance 


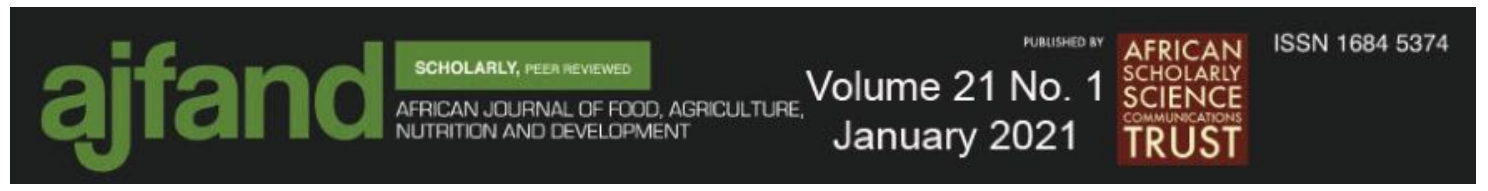

12. FAO. The State of Food and Agriculture 2019. Moving forward on food loss and waste reduction. Rome. Licence: CC BY-NC-SA 3.0 IGO.

13. Shahbandeh M Corn - Statistics \& Facts 2018; Retrieved from https://www.statista.com/topics/986/corn/ Accessed on 1/4/2020.

14. FAO. Rice Market Monitor 2019. Accessed from http://www.fao.org/3/I9243EN/i9243en.pdf Accessed on 1/4/2020.

15. Statista. Rice consumption worldwide in $2018 / 2019$, by country (in 1,000 metric tons) 2019. Available form https://www.statista.com/statistics/255971/topcountries-based-on-rice-consumption-2012-2013/ Accessed on 3/4/2020.

16. Siziba S, Nyikahadzoi K, Makate $\mathbf{C}$ and $\mathbf{N}$ Mango Impact of conservation agriculture on maize yield and food security: Evidence from smallholder farmers in Zimbabwe. African Journal of Agricultural and Resource Economics AFJARE 2019; 14(2): 89-105.

17. European Union. Global food consumption growth and changes in consumer preferences 2019. Accessed from https:/ec.europa.eu/info/news/global-foodconsumption-growing-faster-population-growth-past-two-decades-2019-sep10 en Accessed on 11/6/2019.

18. OECD-FAO. Agricultural Outlook 2018-2027 2019. Available from http://www.fao.org/3/i9166e/i9166e Chapter3 Cereals.pdf Accessed on $1 / 4 / 2020$.

19. World Bank. The World Bank: Transformation of Agriculture Sector Program 4 PforR (P161876) 2018.

http://documents.worldbank.org/curated/en/427881523467764932/pdf/Appraisa 1 Accessed on 1/2/2020.

20. Rehman A, Chandio AA, Hussain I and L Jingdong Fertilizer consumption, water availability and credit distribution: Major factors affecting agricultural productivity in Pakistan. Journal of the Saudi Society of Agricultural Sciences 2019; 18(3): 269-274.

21. AFR. National financial inclusion strategy (2019- 2024); Kigali, Rwanda 2019.

22. NISR. Seasonal Agricultural Survey, Kigali: National Institute of Statistics of Rwanda 2016.

23. AFR. National financial inclusion strategy (2019- 2024); Kigali, Rwanda 2019.

24. Bidogeza JC, Berentsen PBM and J De Graaff A typology of farm households for the Umutara Province in Rwanda. Food Security 2009; 1: 321. https://doi.org/10.1007/s12571-009-0029-8 


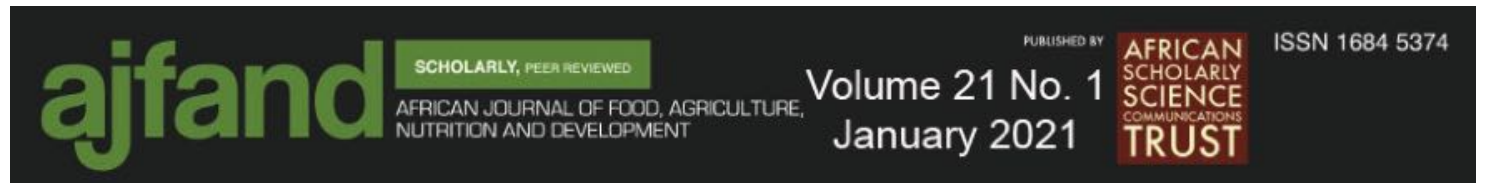

25. MINAGRI. National rice development strategy (2011-2018); Kigali, Rwanda 2013. Available from https://riceforafrica.net/images/stories/PDF/rwanda revised_aug2013.pdf Accessed on 4/7/2020.

26. Krejcie RV and DW Morgan Determining Sample Size for Research Activities Educational and Psychological Measurement 1970; 30: 607-610.

27. Kuivanena KS, Alvareza S, Michalschecka MS, Adjei-Nsiahb K, Descheemaekerc S, Mellon-Bedib S and JCJ Groota Characterizing the diversity of smallholder farming systems and their constraints and opportunities for innovation: A case study from the Northern Region, Ghana. NJAS Wageningen Journal of Life Sciences 2016; 78: 153-166.

28. Frelat R, Santiago Lopez-Ridaura KE, Giller MH, Sabine D, Agnes AD, Olaf E, Ben H, Menale K, Birthe KP, Cyrille R, Randall S, Ritzema DR, Piet J A, van A, Mark T and W Van Drivers of household food availability in sub-Saharan Africa based on big data from small farms. Proceedings of the National Academy of Sciences 2016; 113(2):458-463; https://doi.org10.1073/pnas.1518384112

29. Anderson J, Colleen E, Learch and TG Scott Understanding their demand for financial, agricultural, and digital solutions 2016. Available from https://microdata.worldbank.org/index.php/catalog/2574/download/42008

30. Muvunyi L Maize shortage looms despite bumper harvest 2019. Accessed from http://rwandatoday.africa/news/Maize-shortage-looms-despite-bumperharvest/4383214-5102248-r3d1cqz/index.html

31. USAID. Agriculture and Food Security 2018. Retrieved from https://www.usaid.gov/rwanda/agriculture-and-food-security, 2018

32. Celia AH, Zo LR, Nalini SR, Radhika D, Hery R, Rivo HR, Haingo R and JL MacKinnon Extreme vulnerability of smallholder farmers to agricultural risks and climate change in Madagascar 2014. https://doi.org/10.1098/rstb.2013.0089

33. Ferreira T Does education enhance productivity in smallholder agriculture? Causal evidence from Malawi 2018. Available from https://www.ekon.sun.ac.za/wpapers/2018/wp052018/wp052018.pdf Accessed on $7 / 7 / 2019$.

34. Sitko NJ and TS Jayne Structural transformation or elite land capture? The growth of "Emergent" farmers in Zambia. Food Policy 2014; 48:194-202.

35. Larson DF, Larson KO, Matsumoto $\mathbf{T}$ and $\mathbf{T}$ Kilic Should African rural development strategies depend on smallholder farms? An exploration of the inverse-productivity hypothesis. Agricultural Economics 2014;45(3):355-367. 


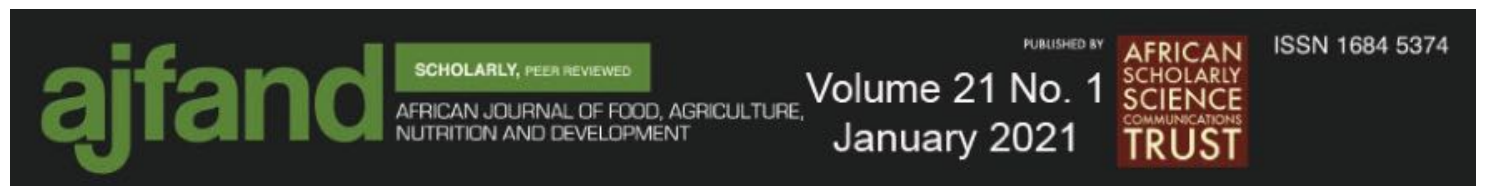

36. Chandio AA and Y Jiang Determinants of credit constraints: Evidence from Sindh, Pakistan. Emerging Markets Finance and Trade 2018a; 54 (15): 34013410 .

37. Chandio AA, Yuansheng JFW, Abdul R and L Dan Farmers' access to credit: Does collateral matter or cash flow matter? Evidence from Sindh, Pakistan. Cogent Economics and Finance 2017; 5: 1369383.

38. Nguyen TD and HT Le Enhancing formal credit accessibility of pig production households in Thai Binh province, Vietnam. International Journal of Economics, Commerce and Management 2015; 3(4): 1-15.

39. Mazzù $\mathbf{S}$ and $\mathbf{F}$ Muriana A strategic approach to non-performing loans treatment in banking: options and rules for decision-making. International Research Journal of Finance and Economics 2018; 166:34-53. 